\title{
Coordinating the machine: subnational political context and the effectiveness of machine politics
}

\author{
Inga A.-L. Saikkonen ${ }^{1}$ (])
}

Accepted: 2 December 2020 / Published online: 19 March 2021

(c) The Author(s) 2021

\begin{abstract}
Political machines use state resources to win elections in many developing democracies and electoral autocracies. Recent research has noted that the coordination of machine politics can be much more complex and problem-prone than previously thought. Yet, the role that the subnational political context plays in solving these coordination problems has largely been neglected in the comparative literature. This article seeks to fill this gap and suggests that control over the local administration is an important variable that shapes the effectiveness of authoritarian machine politics. We exploit the great institutional and political variation within one of the most prominent electoral authoritarian regimes of today, the Russian Federation, to test the empirical implications of the theory with detailed local level electoral and socio-economic data as well as multilevel regression models. The empirical results highlight the importance of subnational political structures in supporting electoral authoritarian regimes.
\end{abstract}

Keywords Clientelism · Machine politics $\cdot$ Electoral manipulation $\cdot$ Subnational politics $\cdot$ Russia

\section{Introduction}

In many developing democracies and electoral autocracies political machines ${ }^{1}$ use state resources ${ }^{2}$ to win elections. Burgeoning literature has studied the role that clientelism and machine politics play in many elections around the world (Gherghina 2013; Hicken 2011; Kitschelt and Wilkinson 2007; Stokes 2005;

\footnotetext{
${ }^{1}$ Political machines are (informal) organizations that seek to influence electoral outcomes by e.g. driving up electoral turnout or vote for a particular party/candidate. They are headed by a patron and consist of a web of lower level agents, 'brokers'.

${ }^{2}$ Such as fiscal resources, or access to welfare services and state jobs.
}

Inga A.-L. Saikkonen

inga.saikkonen@abo.fi

1 Social Science Research Institute, Åbo Akademi University, 20500 Turku, Finland 
Stokes et al. 2013). Yet, recent research has also noted that clientelistic electoral strategies are by no means cost-free nor necessarily that efficient as they require complex delegation and coordination at several levels of the electoral 'machine'. Recent literature has highlighted these problems, and shown that the agents conducting electoral manipulation can be very unreliable (Szwarcberg 2012a, b, 2013; Stokes et al. 2013; Camp et al. 2014; Larreguy et al. 2016; Rundlett and Svolik 2016; Camp 2017). The coordination of machine politics is thus shown to present a set of complex principal-agent problems for political leaders. How do political machines mitigate these delegation issues?

The extant literature has only begun to probe these questions. Existing studies have shown that political machine leaders seek to monitor the agents conducting the manipulation, and reward and sanction them for good performance (Kynev et al. 2012; Szwarcberg 2012a, b; Larreguy et al. 2016). However, less attention has been paid on factors that would make this monitoring and the reward/punishment regime effective. The conduct of electoral manipulation is fundamentally a local phenomenon (Rundlett and Svolik 2016). Electoral manipulation thus always takes place in a particular local and subnational environment. These settings are governed by powerful local patrons who coordinate and monitor the conduct of machine politics in their designated area, and can reward/punish lower level agents on the basis of their results (such as polling station level electoral returns). Despite this, comparative literature has until now largely neglected the role that the local political context and subnational arrangements plays in shaping machine politics effectiveness, although the emerging spatial work on electoral manipulation has shown that the intensity and types of electoral manipulation can exhibit very distinct local geographical patterns within countries (Cantu 2017; Skovoroda and Lankina 2017). This article seeks to fill this gap and suggests that the structure of the local state administration is an important variable that shapes the effectiveness of the coordination of electoral manipulation, and that it explains why we see considerable differences between machine politics effectiveness between different subnational areas in countries. Building on (neo)institutional literature on politics and the economics of organization literature, this article tests two sets of causal explanations on how the local political context could shape machine politics effectiveness. First, many authoritarian states, including the Soviet Union, have found hierarchically structured bureaucracies and local government organizations as effective means of organizing governance (on this, see, e.g., Roeder 1993). The first hypothesis tested in this article probes the effectiveness of hierarchically organized local administrations structures in coordinating machine politics effectiveness. Second, we test how more informal means of control, such as the local principal's tenure in office, shape the coordination of machine politics. The article exploits the great institutional and political variation within one of the most prominent electoral authoritarian regimes of today, the Russian Federation, to test the empirical implications with detailed local level electoral and socio-economic data as well as multilevel regression models. The results show that hierarchically appointed local administration structures are very effective in machine politics mobilization. Overall, the findings of this article highlight the importance of subnational politics in stabilizing electoral authoritarian regimes. 
The findings of this article contribute to the emerging literature on agency problems in machine politics coordination (Szwarcberg 2012a, b, 2013; Stokes et al. 2013; Camp et al. 2014; Larreguy et al. 2016; Camp 2017). ${ }^{3}$ Moreover, this article is one of the first studies to highlight the role that the subnational political context plays in solving the agency problems in machine politics delegation, ${ }^{4}$ and shows that it has a powerful effect on electoral manipulation effectiveness.

\section{Coordination problems and machine politics effectiveness}

Authoritarian leaders have a broader set of electoral strategies to choose from than democratic politicians. In addition to electoral strategies used also in democracies, such as political business cycles and targeted public spending, authoritarian incumbents can also resort to vote buying, voter intimidation ${ }^{5}$ and electoral fraud to maintain power. However, recent literature has begun to question the effectiveness of these strategies. Recent studies have shown that electoral manipulation suffers from delegation and coordination problems as the actual vote buying/manipulation needs to be delegated to a complex web of lower level agents (brokers). This delegation is risky and can lead to highly suboptimal targeting of vote buying/electoral manipulation (see, e.g., Stokes et al. 2013; Rundlett and Svolik 2016).

The organization of machine politics-how to coordinate complex hierarchies of local agents and make them comply with potentially illegal activities-thus presents a rather thorny principal-agent problem for political leaders. Despite these agency problems, electoral fraud and clientelism are still frequently used in many autocracies and new democracies in the world. How do political machines solve these delegation issues?

Emerging comparative literature has begun to probe these questions. In some cases, such as in Argentina, clientelistic exchanges are coordinated by institutionalized mass parties and the career incentives within the party mitigate the problem of broker shirking (Szwarcberg 2012a, b). ${ }^{6}$ Yet, recent literature has shown that principal-agent problems can abound even in such conditions, and that brokers, even when they are co-partisans, tend to be unreliable agents of the party patrons (Stokes et al. 2013). Moreover, in many of the countries in the world (and in many historical cases) machine politics is not primarily conducted via a disciplined network of party

\footnotetext{
${ }^{3}$ While most of the literature on clientelism examines the horizontal relationships between the brokers and the clients, or more recently, between the machine leaders and the brokers, emerging literature has also begun to examine other horizontal clientelistic mechanisms, such as the relationship between political parties and private contributors (see Gherghina and Volintiru 2017).

4 For an exception, see Larreguy et al. (2015), who examine how the location of polling stations affects the ability of machine leaders to monitor the work of political brokers.

5 That is, threatening the voters with sanctions such as losing their jobs or access to welfare benefits if they vote the 'wrong' way (see, e.g., Mares and Young 2016).

${ }^{6}$ In Argentina, brokers are local, partisan councillors whose electoral fortunes depend partly on their patrons, creating incentives to 'work' for the party. However, as Szwarcberg (2012a, b) notes, even these incentives do not fully prevent broker shirking.
} 
operatives, but machine leaders leaders have to rely on local notables to coordinate voter intimidation and electoral fraud on their behalf (Ziblatt 2009; Frye et al. 2014; Mares and Zhu 2015; Forrat 2018). ${ }^{7}$ For example, even in Mexico, with a strong institutionalized mass party (PRI), the actual conduct of machine politics appears to be contracted to non-partisan local operatives who have more information about the local conditions than the party operatives (Larreguy et al. 2016).

How do political leaders then discipline the work of these local operatives in the absence of formal coordinating institutions? Most comparative studies suggest that political machines tend to rely on 'classic' solutions to principal-agent problems (see, e.g., Moe 1984), such as by monitoring the work of local brokers and punishing and rewarding the local agents accordingly. Political machines are known to spend considerable resources on broker monitoring (on this, see, e.g., Camp 2017). Most commonly, machine leaders appear to use polling station level electoral returns to monitor the efficiency of the brokers in delivering votes (for evidence from Mexico, Russia, Argentina and Venezuela, see Kynev et al. 2012; Stokes et al. 2013; Larreguy et al. 2016), and use various rewards and punishments to control the work of the local intermediaries. For example, in Argentina, effective brokers are rewarded by electoral assistance, and in Russia, municipal leaders can be promoted on the basis of electoral performance in 'their' localities (Kynev et al. 2012; Szwarcberg $2012 \mathrm{a}, \mathrm{b}$ ). Officials higher up in the government hierarchy, such as subnational governors, can also be monitored for their ability to deliver votes for the regime (for evidence from Russia, see Reuter and Robertson 2012; Reisinger and Moraski 2017). Thus, political leaders in various contexts seem to be keenly aware of the agency problems in machine politics and seek to mitigate these by actively monitoring the ability of lower level agents to deliver votes for the machine.

What are the factors that shape the effectiveness of this monitoring and reward/ punishment regime? The conduct of electoral manipulation is fundamentally a local phenomenon (Rundlett and Svolik 2016). Electoral manipulation thus always takes place in a particular local and subnational environment. These settings are governed by powerful local patrons who coordinate and monitor the conduct of machine politics in their designated area, and can reward/punish lower level agents on the basis of their results (such as polling station level electoral returns, as noted above). Despite this, comparative literature has until now largely neglected the role that the local political context and subnational arrangements plays in shaping machine politics effectiveness. This can be especially salient in large federal states where the local administration can be arranged in different ways. This article seeks to fulfil that gap and suggests that the subnational setting is an important variable that shapes the effectiveness of the coordination of electoral manipulation, and that it explains why we see considerable differences between machine politics effectiveness between different subnational areas in countries. This article builds on the institutionalist literature on politics and tests two sets of causal explanations of the role that different types of subnational political settings may play in coordinating machine politics. We

\footnotetext{
7 Such as local officials in historical Prussia (Ziblatt 2009), or employers in today's Russia (Frye et al. 2014).
} 
investigate the role that a hierarchical way of structuring the local government institutions and the more informal ways of controlling the local level agents, such as the principal's tenure, have on machine politics effectiveness.

\section{Machine politics in Russia}

Russian federal elections have become increasingly uncontested from the early 2000s onwards. Electoral manipulation has played an important part in Russian elections (see, e.g. Myagkov et al. 2009; Mebane and Kalinin 2010). Most of the current scholarship argues that electoral mobilization in Russia is mostly focused on driving up electoral turnout and mobilizing particular 'malleable' sectors of the population to the polls, such as or rural and socio-economically vulnerable sectors of the population (see Hale 2003; Allina-Pisano 2010; Kynev et al. 2012; Frye, et al. 2014). Common non-programmatic methods of mobilizing the 'right' sectors to the polls involve electoral intimidation at the workplace or at universities, or voter intimidation targeting the elderly and other vulnerable sets of population, in particularly in rural areas (see, e.g. Kynev et al. 2012; OSCE/ODIHR 2012; Frye et al. 2014; Harvey 2016). Socio-economic dependency on the state makes these sectors of people susceptible to voter intimidation, and they are often reliant on state-controlled media (especially state TV) for their political information (Kynev et al. 2012). Electoral results can also be augmented by outright electoral fraud, such as the falsification of final vote counts or ballot box stuffing (on the latter, see Myagkov et al. 2005, 2009; Goodnow et al. 2014).

Both of these methods of electoral manipulation require careful delegation at several levels of the state administrative machine. Machine politics in Russia have developed on a distinctly non-partisan basis, and subnational and local administration structures play an important role in coordinating voter mobilization. The responsibility of 'delivering' votes on behalf of the Kremlin was delegated to the largely non-partisan Russian subnational political machines in the early 2000s (see, e.g., Hale 2003; Reuter and Remington 2009; Golosov 2013). The Russian Federal Centre recognized the need to gain the support of the powerful regional political machines in elections already in the 1990s (Reuter 2017). However, the Kremlin was able to gain their support only gradually in the early 2000s after "the surge in oil prices, a growing economy and Putin's high popularity ratings [had] strengthened the federal center vis-à-vis the regional elites" (Reuter 2017, p. 107; see also Golosov 2013). The process of the Kremlin gaining the upper hand over the regional elites culminated in the removal of the gubernatorial elections after the Beslan hostage crisis in 2003 (although the governors also obtained some smaller concessions from the centre in return, see Reuter 2017). Several studies have shown that the Russian regional governors are held accountable for their success in mobilizing votes for the Kremlin in federal elections (Reuter and Robertson 2012; Reisinger and Moraski 2017). Regional governors on their turn are known to delegate voter mobilization to powerful local 'meso-elites', such as mayors or powerful 'rayon' ('county') heads, who control 'sub-pyramids' of local brokers (Matzusato 2001a, b; Buzin et al. 2012; Sharafutdinova 2013). The rayon heads control the lower level brokers, such 
as state-connected enterprise managers (Frye et al. 2014), managers of the former state farms (Allina-Pisano 2010), or other local notables, such as doctors and teachers (Forrat 2018), who can be bribed/coerced into participating in electoral commissions with offers of money and threats of losing their jobs. Post-Soviet machine politics is thus conducted via a multi-layered 'pyramid' with complex chains of delegation. Yet, the effectiveness of machine politics has varied markedly between and within the subnational regions in Russia (Hale 2003; Reisinger and Moraski 2017). What accounts for this variation in the subnational machines' ability to 'deliver' votes? The next section proposes two sets of theoretical explanations accounting for this variation.

\section{Varieties in sub-national political organization and machine politics effectiveness in Russia}

Different types of organizations tend to function most effectively when they are arranged in a hierarchical setting, and the economics of organization literature has long noted that most firms tend to be organized in a hierarchical manner (for a discussion, see Moe 1984). Various authoritarian states have also found that the power of appointment and removal are highly efficient ways of controlling lower level agents. For example, the nonmenklatura system functioned as an effective means of organizational control in the Soviet Union. As Roeder has noted, "[t]he key to [bureaucratic] control [in the Soviet Union] was the accountability of bureaucratic personnel to the Central Committee through its powers of appointment and removal" (Roeder 1993, p. 46). The control over the appointment and removal of the personnel should be especially powerful in an authoritarian setting where legal arbitrariness means that appointments and promotions are often highly politicized (Gehlbach and Simpser 2015). Direct subnational appointments provide more manageable 'chains of command' at the local level, and make the local officials directly 'beholden' to their higher-up patrons. Electoral manipulation, too, should be much more efficient to coordinate in settings with a directly appointed subnational administration with direct 'chains of command'.

Therefore, we hypothesize that:

Hypothesis 1 Machine politics is likely to be more effective and the share of proregime votes higher in subnational localities where local administration structures are hierarchically appointed.

The second informal aspect which should affect the degree of uncertainty in a subnational political setting is the length of incumbency of the subnational political patron. Governance systems in authoritarian settings are highly personalised (Hale 2015), and thus the tenure of key personnel should affect the stability of the local organizational setting markedly. A longer tenure by the local incumbent should create informal networks and settled hierarchies that can regularize and coordinate the 
workings of local organizations. Therefore another subnational setting in which machine politics coordination should be more effective is established strongholds where the local patron has been in power for a long time. These settings should feature more developed informal hierarchies that coordinate the local political processes.

Thus the second hypothesis tested in this article is:

Hypothesis 2 Machine politics is likely to more effective and the share of proregime votes is likely to be higher in subnational localities where the subnational incumbent has been in power for longer.

\section{Empirical approach and data}

\section{Subnational institutional variation in Russia}

The Russian Federation presents a particularly useful case to investigate the effects of variation in subnational administrative structures as there has been considerable differences in both the formal and informal ways that the Russian regional and municipal politics have been organized. In the 2000s, all local level government structures were meant to be popularly elected. However, a small number of subnational leaders, 'governors', recognized the advantage of hierarchical local administration systems, and resisted the central government's calls for local elections (on this, see, e.g., Brie 2004; Lankina 2004). For example, the most important local government officials, the local mayors, were directly appointed by the local governor in around $14 \%$ of the Russian subnational areas, 'regions' (Gel'man and Lankina 2008), but remained elected in other subnational regions. ${ }^{8}$ From the mid-2000s onwards the Russian Federal Centre's "initiatives to recentralize power resulted in the cancellation of direct elections in just under half of all cities" (Buckley et al. 2014, p. 91). There were also great differences in the tenure of the Russian local governors before the cancellation of the gubernatorial elections in 2004. Some local executives, such as the President of Tatarstan, Minitimer Shaimiev, had held supreme power in their subnational units since the Soviet times, ${ }^{9}$ whereas other regions, such as Smolensk Oblast, had very unsettled 'elite situations' and frequent changes in governorship.

\footnotetext{
8 These types of arrangements were more common in titular republics, but emerged also in some nonethnic regions, such as Orel Oblast and Moscow City (see, e.g., Brie 2004).

9 Mintimer Shaimiev acted as the republic's president until 2010 when he was appointed as the State Counselor of the Republic of Tatarstan.
} 


\section{Data}

\section{Dependent variables}

We specify a series of multilevel models where our outcomes of interest are electoral turnout and the vote share for the winning candidate in the 2004, 2008 and 2012 presidential elections in Russia to test the theoretical hypotheses. Thus the effectiveness of the local political machines is operationalised by the share of proregime votes in a series of Russian elections. The winning candidates in these elections were Vladimir Putin in the 2004 and the 2008 elections and Dmitry Medvedev in the 2012 presidential contest. ${ }^{10}$ Electoral turnout serves as an important indicator of regime performance in authoritarian regimes, as low electoral turnout can signal 'latent' dissatisfaction with the regime (Magaloni 2006). Therefore electoral mobilization in Russia focuses on both driving up electoral turnout as well as mobilizing votes for pro-regime candidates (on turnout mobilization see, e.g., Kynev et al. 2012; Frye et al. 2014).

\section{Independent variables}

We use original socio-economic and institutional data from Russia aggregated at both the region and county (rayon) levels to test the theoretical expectations. ${ }^{11}$ Hypothesis 1 expects machine politics to be more effective in subnational settings where the local administration has been hierarchically appointed rather than popularly elected, which is operationalized by a dichotomous variable (Hierarch Admin) which indicates whether the local mayors were hierarchically appointed (coded "1") or elected in a given region. ${ }^{12}$ Hypothesis 2 expects that a longer gubernatorial tenure would be associated with more effective machine politics, and this is operationalized by the number of years the governor has been in power in the given region

\footnotetext{
${ }_{10}$ The electoral data comes from the CD-rom "Rossiiskie vybory v tsifrakh i kartakh. 1995-2007" as well as the website of the Central Electoral Commission of Russia.

11 The dataset combines electoral data with Russian 2002 census data. The lowest level at which both electoral and census data is available is at the rayon ('county') level. The rayons ('counties') are nested within the larger administrative units ('regions'). A small number of rayons had to be excluded due to redistricting or missing data. The results presented here include observations from all the regions that consistent time-series institutional and economic indicators are available for, i.e. 19 titular republics, 6 krays and 49 oblasts.

12 The variable was coded from the data presented in Buckley et al. (2014) which represents the most up-to-date and comprehensive indices on the Russian local government appointment structures. The variable was coded as " 1 " if the mayors of regional capitals- the most important power centers in the region-were appointed in the period in the run-up to the 2004/2008/2012 elections.
} 
(Tenure). ${ }^{13}$ The explanatory variables are measured at the regional level and are expected to have a positive association with the outcome variables.

\section{Main control variables}

Our models include several control variables at both the region and rayon levels, drawn from both the Russia-specific and comparative literature. The models include two sets of regional level controls. Economic growth is shown to be continually associated with better electoral performance of the Russian regime in several studies (see e.g. Treisman 2011), and thus the models control for the lagged GRP per capita growth at the regional level, with data from the Russian Federal Service for State Statistics, Goskomstat. Previous literature also suggests that delegation problems are likely to be greater in larger regions (Hale 2003) and the models control for the size of the region operationalized by the number of rayons per region.

The models also include several variables measured at the rayon level that are shown to be powerful predictors of electoral turnout and voting behaviour in Russian elections. Previous studies show that the regime performs better in rayons with high levels of rural inhabitants and non-Russian electorate (Clem and Craumer 1997, 2000; Goodnow et al. 2014; Reisinger and Moraski 2017; Saikkonen 2017, 2019; White 2016; White and Saikkonen 2017), and the models include controls for the share of agricultural workers, and the percentage of non-Russian people at the rayon level. Pensioners are also thought to be particularly pliable for voter mobilization in Russia due to their dependence on state transfers, and their socialization in electoral participation under the Soviet regime (Hale 2003), and thus the models control for the percentage of pensioners per rayon. Political machines also target poor and state-dependent voters (see, e.g., Calvo and Murillo 2004; Stokes 2005), and thus the models include the share of people per rayon who receive government transfers. In addition, the models control for the education profile of the locality (see e.g. Colton 2000). The models also control for rayon size, which is operationalized by the number of registered voters per rayon (logged), as voter monitoring is likely to be easier in smaller and socially more integrated communities (Stokes 2005). Numerous studies have shown that Russian elections have become increasingly fraudulent in the 2000s (see, e.g. Mebane and Kalinin 2010; Myagkov et al. 2005, 2009). Following the literature on electoral manipulation in Russia that uses turnout thresholds as an indirect indictor of fraud and ballot-box stuffing (Goodnow et al. 2014; White 2016) we use a dichotomous indicator of fraud that assesses whether rayonlevel electoral turnout is greater than 1.5 standard deviations above the rayon-level

13 The variable measures the length of an individual's tenure as the effective head of the region. Most governors became heads of the region when they were either elected as governors or appointed to the position by President Yeltsin. However, in some cases, the local executives had been in power longer than this. For example, the president of Tatarstan, Mintimer Shaimiev, had ruled Tatarstan since 1989, when he was elected as the first secretary of Tatarstan Communist Party's regional committee (which then held supreme power in the region). The variable was coded until the year 2004 as after that the regional governors lost their political independence and begun to be appointed by the federal centre. The data was collated from McFaul and Petrov (1998), Orttung et al. (2000) and online sources. 
national average. While most indicators of electoral fraud always contain a variable amount of 'noise', this indicator has been shown to capture instances of ballot-box stuffing rather well in numerous recent empirical studies (Goodnow et al. 2014; White 2016).

\section{Results}

The statistical analysis is conducted by estimating hierarchical linear (random intercepts) models. Multilevel models take into account the nested nature of the data, and they are especially suited to test the effects of variables at two levels (Rabe-Hesketh and Skrondal 2005).

The main empirical results are presented in Table 1. The results offer strong support for the hypothesis (Hypothesis 1) that machine politics would be more effective in non-elected subnational settings. The results from Models 1 to 6 suggest that association between the hierarchically appointed local administration structures and pro-regime electoral results remains robust and highly statistically significant throughout the various models. The effect sizes are also substantive. For example, the results regarding the 2004 presidential elections (M1 and M2) suggest that the vote share for Vladimir Putin was almost 5 percentage points higher, ceteris paribus, in regions where local administration officials were hierarchically appointed from above, and that electoral turnout was almost 7 percentage points higher in similar settings. It is notable that we find such substantive effects in models that control for a host of other powerful covariates, including the proxy for electoral fraud. Models 1 and 2 also test Hypothesis 2. Since the Russian governors lost their independent power positions in 2004 it makes sense to test Hypothesis 2 only with data running up to 2004. The results do not offer much support for Hypothesis 2, that is, that the governor's tenure would have an effect on machine politics effectiveness. These results suggest that the formal mechanisms of subordinate control are more effective in political machine control than the more informal mechanisms. In terms of the other control variables, the results are mostly in line with the findings of previous studies.

Table 2 presents a robustness check of the previous results using an alternative indicator on the independence of local administration structures. These models are run with an indicator measuring the independence of local administration bodies in Russia (Local Gov). This indicator comes from the widely used Index of Democracy, an expert rating of democratization in the Russian regions. ${ }^{14}$ The direction of the coefficient is expected to be negative. The results are largely robust to the use of this alternative indicator, apart from the coefficient in Model 1 that fails to achieve statistical significance, but is to the expected direction. All the other coefficients are statistically significant.

\footnotetext{
14 The indicators are available at Petrov and Titkov. "Indeks demokratichnosti." Sotsial'nyi atlas rossiyskikh regionov, accessed at http://atlas.socpol.ru/indexes/index_democr.shtml.
} 


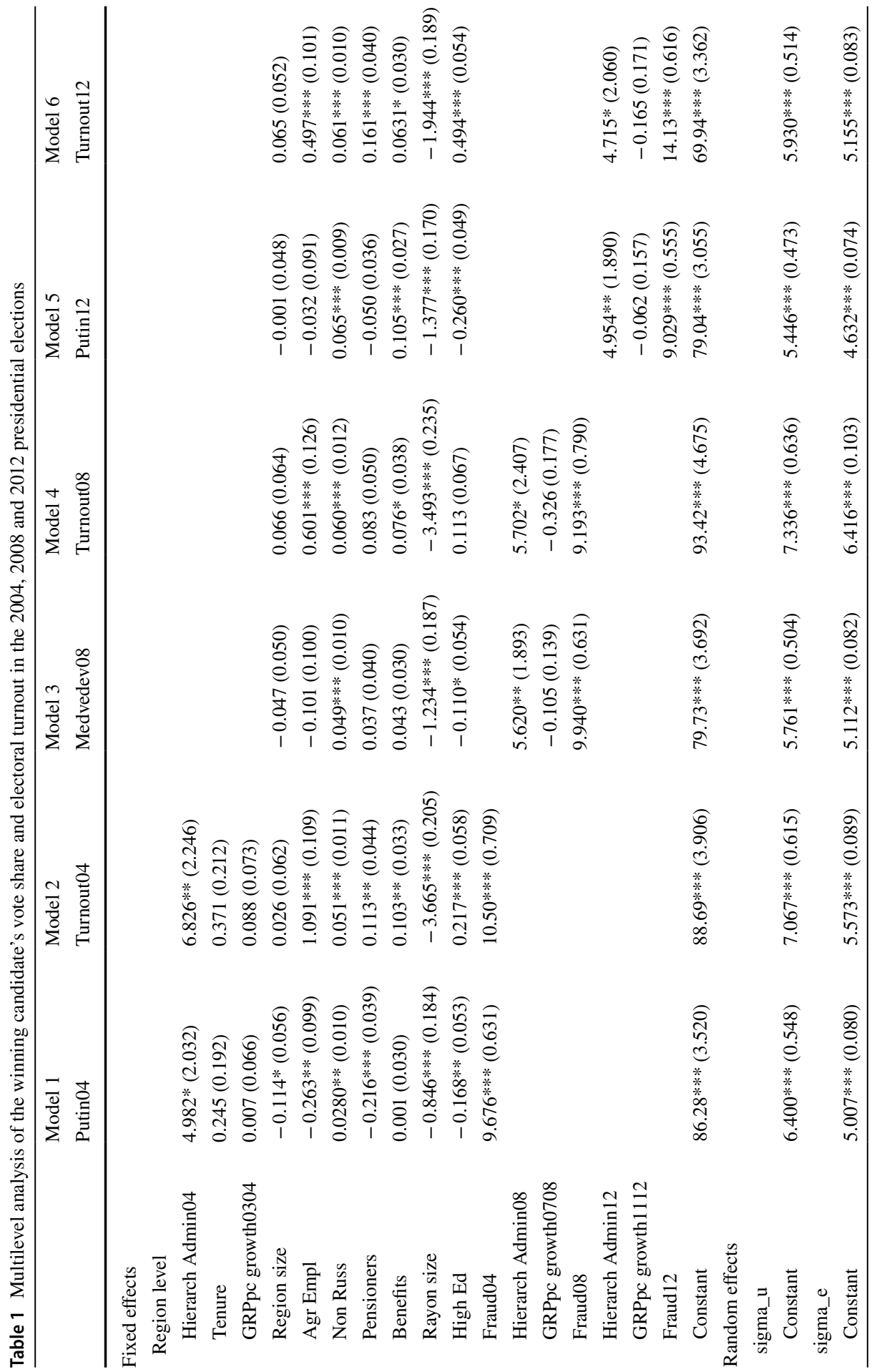

尔 


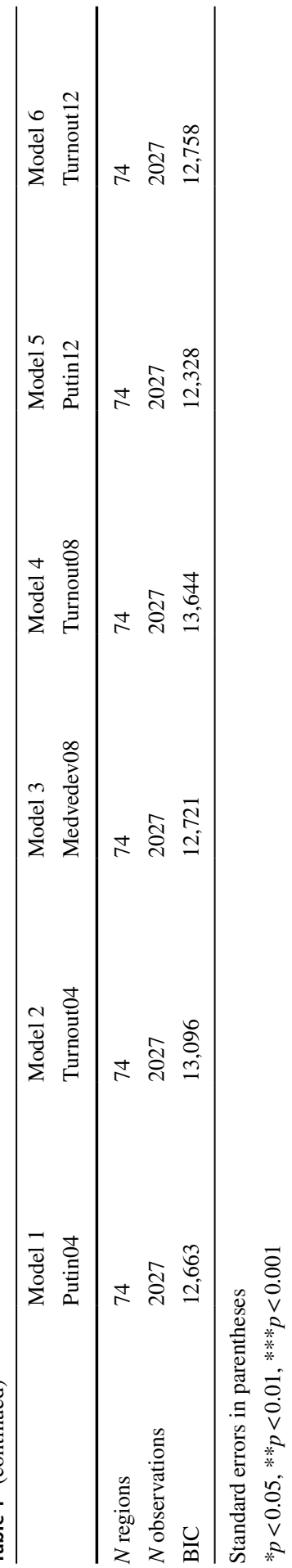




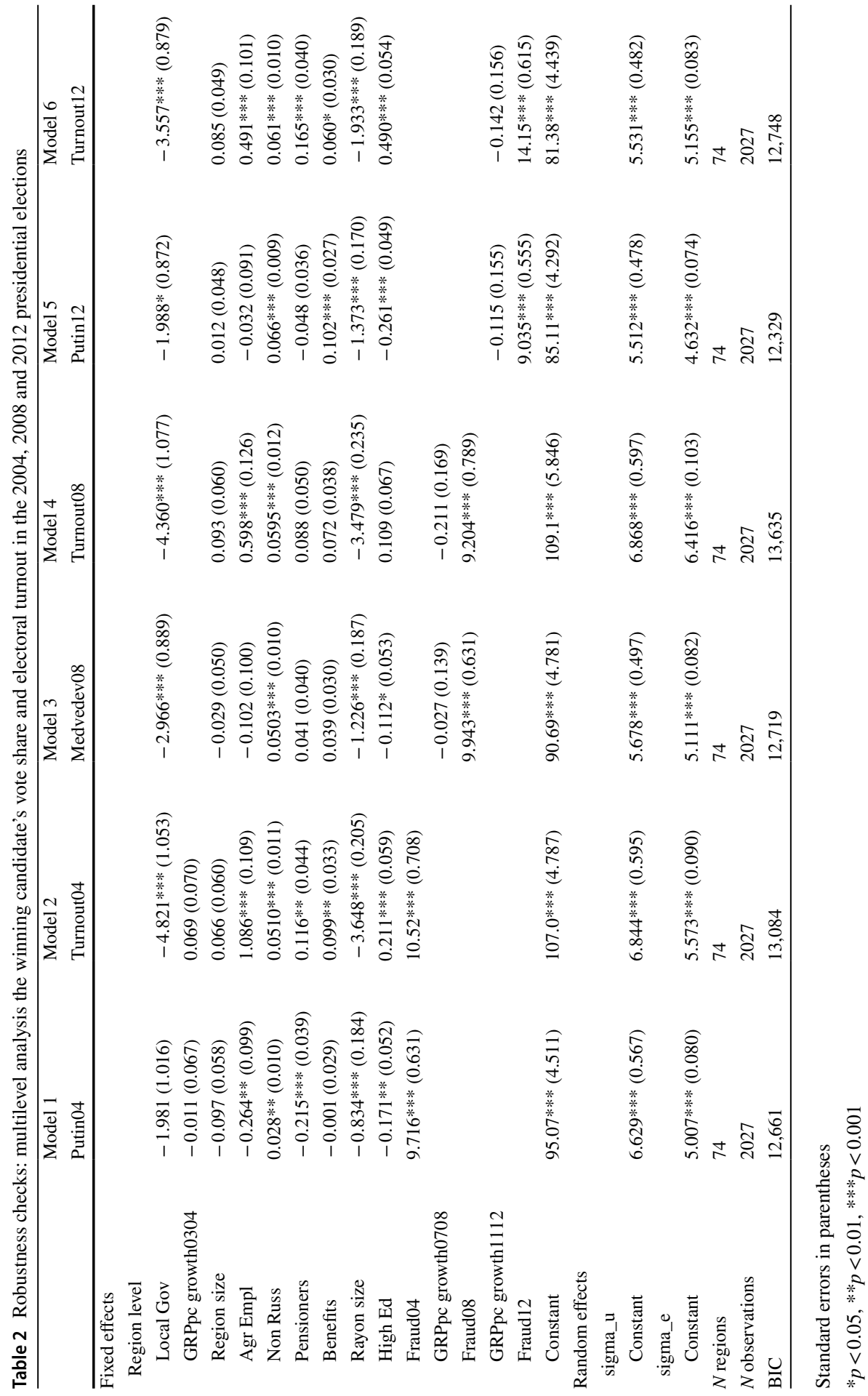

站。 
In summary, the results support the theoretical expectation that hierarchical forms of local governmental organization are a crucial variable in shaping the effectiveness of machine politics. Much of the previous literature has considered the effectiveness machine politics in Russia as a function of the mobilization of particular 'pliable populations' such as ethnic minority populations, rural populations, and other state dependent sectors of the electorate (Hale 2003, 2007; Golosov 2013). It is therefore notable that we can find such strong statistical effects even when these powerful covariates are controlled for both at the rayon and region levels. The results presented here augment the previous studies in important ways, as they demonstrate the importance of the political context that coordinates machine politics at the local level and makes the mobilization of these sectors of population possible.

There are naturally limitations to this analysis. Gubernatorial tenure is a rather 'noisy' variable, and the null findings related to it may well be explained by the lack of nuance in measuring this variable. More thorough research would be needed to fully probe the role of the gubernatorial political machines in supporting the federal political machine. This would entail taking into account the power resources that the governors possess, such as, for example, their membership of United Russia, their relationships with the federal centre and their connections to major financial-industrial groups (see e.g. Reuter 2010). Further research should therefore probe what role these resources play in 'delivering' pro-regime votes for the centre. However, the overall empirical results from the analysis above highlight the thus far largely understudied role of the local administration structures in shaping the effectiveness of authoritarian machine politics.

\section{Regional political machines and hierarchically appointed local government institutions}

The role of the hierarchically appointed local administration in electoral mobilization can be illuminated by the strong political machines built by Yuriy Luzhkov in Moscow City and Mintimer Shaimiev in the Republic of Tatarstan. The Moscow City local administration was reorganized in the 1990s so that the heads of the administrative districts became personally appointed by the mayor, forming a "hierarchical system of personal responsibility from top to bottom" (Brie 2004, p. 210). This created a powerful political machine in the city that enabled the mobilization of the electorate via socio-economic patronage (Brie 2004). Kimitaka Matzusato has described the Tatarstan republican administration as a type of 'centralized caciquismo' where the "local bosses play the role of intermediary brokers between the central authorities and local communities" (Matzusato 2001a, p. 54, see also Sharafutdinova 2010 on the local political machine in Tatarstan). The local mayors and the rayon (county) heads were hierarchically appointed by the republican leadership, and became "responsible not only for various administrative functions, but also for the results of elections in their regions or localities" (Ibid., p. 55). As Matzusato describes, the local administration heads were "not bureaucrats in the Weberian sense, but boss politicians who are responsible for running electoral machines for the sake of higher authorities" (2001b, p. 189). Their performance in 'delivering' 
votes was closely monitored and controlled from above. Matzusato also argues that the hierarchical appointment system was crucial to the functioning of machine politics in Tatarstan. "The appointment system of local chief executives in Tatarstan has been aimed mainly at preserving a single, indivisible electoral machine" (2001a, p. 56). Similar evidence of using the local administration subordinates in electoral mobilization has been reported from Ukraine (see Allina Pisano 2010). In other regions, where the local administration was not under the control of the governor, regional politics often became very conflictual and the governors and the mayors developed distinct sets of administrative clientele. For example, in Pskov Oblast, the regional governor and the Pskov City mayor both developed a distinct sets of local clientele that mobilized votes for the governor from the countryside and support for the mayor in urban areas (Belokurova 2002). A similarly conflictual situation developed in Primor'ye Oblast, where the mayor of Vladivostok and the governor were engaged in an intense conflict (Slider 2004). These examples thus suggest how gaining control of the local administration structures enabled the governors in some regions to create strong political machines under their direct control, whereas in other regions the local clienteles remained more divided.

It is important to note that the regional political machines that developed in Russian subnational level were mostly distinctly non-partisan. Whereas machine politics in other parts of the world have been coordinated by party machines, local administration structures performed the coordinating functions in Russian regional political machines (for a related arguments, see Brie 2004; Hale 2007). These regional political machines were absorbed into the federal political machine in the early to mid-2000s (Reuter 2017). This highlights the need to study the role that local and subnational administrations play in underpinning authoritarian regimes further.

\section{Conclusion}

Various forms of electoral manipulation, such as vote buying or electoral fraud, take place at the very local, grass-roots level, and their execution is often delegated to complex hierarchies of non-partisan actors. Yet, as recent comparative literature has begun to show, this delegation involves considerable agency problems that cannot be fully resolved with increased monitoring of the agents. This article contributes to this literature by highlighting the crucial role that subnational political hierarchies and the local political setting play in coordinating electoral manipulation.

The findings of this article have several implications for the comparative literature on electoral clientelism and authoritarian politics. The findings show how subnational political structures can support authoritarian regimes at the national level. The growing literature on subnational democratization has made valuable contributions in demonstrating how subnational authoritarian enclaves can hold back democratization (see, e.g., Gibson 2013; Whitehead and Behrend 2016). Yet, the crucial role that subnational politics can play in coordinating clientelism and machine politics has been less examined. This article has shown how subnational authoritarian enclaves can become the 'backbones' of the national level authoritarian machine. Yet, much further work is needed to understand the various functions of local and 
subnational politics in authoritarian regimes and how the trajectories of subnational politics affects the stability of the national level authoritarian regime.

Acknowledgements I wish to thank the journal editors and the anonymous reviewers for excellent comments. I also wish to thank Sergiu Gherghina and participants of the presentations at the ECPR Joint Sessions in 2014, APSA Annual Meeting in 2014, ASN Annual Convention in 2015, and a research seminar the MacMillan Center, Yale University for helpful comments on earlier versions of this paper. All remaining errors are naturally my own.

Funding Open access funding provided by Abo Akademi University (ABO). Work for this article was funded by the Academy of Finland (grant number 316897 and 258190).

Open Access This article is licensed under a Creative Commons Attribution 4.0 International License, which permits use, sharing, adaptation, distribution and reproduction in any medium or format, as long as you give appropriate credit to the original author(s) and the source, provide a link to the Creative Commons licence, and indicate if changes were made. The images or other third party material in this article are included in the article's Creative Commons licence, unless indicated otherwise in a credit line to the material. If material is not included in the article's Creative Commons licence and your intended use is not permitted by statutory regulation or exceeds the permitted use, you will need to obtain permission directly from the copyright holder. To view a copy of this licence, visit http://creativecommons.org/licen ses/by/4.0/.

\section{References}

Allina-Pisano, J. 2010. Social Contracts and Authoritarian Projects in Post-Soviet Space: The Use of Administrative Resource. Communist and Post-Communist Studies 43: 373-382.

Belokurova, E. 2002. Pskov: neustranimiy konflikt. In Avtonomiya ili kontrol'? Reforma mestnoy vlasti $v$ gorodakh Rossii, 1991-2001, ed. V. Gel'man, S. Ryzhenkov, E. Belokurova, and N. Borisova. St Petersburg: Evropeiskiy universitet v Sankt-Peterburge and Letniy Sad.

Brie, M. 2004. The Moscow Political Regime: The Emergence of a New Urban Political Machine. In The Politics of Local Government in Russia, ed. A.B. Evans and V. Gel'man. Lanham: Rowman and Littlefield Publishers.

Buckley, N., G. Garifullina, O.J. Reuter, and A. Shubenkova. 2014. Elections, Appointments and Human Capital: The Case of Russian Mayors. Demokratizatsiya: The Journal of Post-Soviet Democratization 22 (1): 87-116.

Buzin, A.Y., V.S. Vakhshtain, A.V. Kynev, and A.E. Lyubarev. 2012. Federal'nye, regional'nye i mestnye vybory v Rossii 4 dekabrya 2011 goda, Analiticheskiy doklad. Moscow: Golos.

Calvo, E., and M.V. Murillo. 2004. Who Delivers? Partisan Clients in the Argentine Electoral Market. American Journal of Political Science 48 (4): 742-757.

Camp, E. 2017. Cultivating Effective Brokers: A Party Leader's Dilemma. British Journal of Political Science 47 (3): 521-543.

Camp, E., A. Dixit, and S. Stokes. 2014. Catalyst or Cause? Legislation and the Demise of Machine Politics in Britain and the United States. Legislative Studies Quarterly 39 (4): 559-592.

Cantu, F. 2017. The Geographical Menu of Manipulation: Bolivia's 2008 Recall Referendum. Houston: University of Houston.

Clem, R.S., and P.R. Craumer. 1997. Urban-Rural Voting Differences in Russian Elections, 1995-1996. A Rayon-Level Analysis. Post-Soviet Geography and Economics 38 (7): 379-396.

Clem, R.S., and P.R. Craumer. 2000. Regional Patterns of Political Preference in Russia: The December 1999 Duma Elections. Post-Soviet Geography and Economics 41 (1): 1-30.

Colton, T.J. 2000. Transitional Citizens, Voters and What Influences Them in the New Russia. Cambridge: Harvard University Press.

Forrat, N. 2018. Shock-Resistant Authoritarianism: Schoolteachers and Infrastructural State Capacity in Putin's Russia. Comparative Politics 50 (3): 417-443. 
Frye, T., O.J. Reuter, and D. Szakonyi. 2014. Political Machines at Work: Voter Mobilization and Electoral Subversion in the Workplace. World Politics 66 (2): 195-228.

Gehlbach, S., and A. Simpser. 2015. Electoral Manipulation as Bureaucratic Control. American Journal of Political Science 59 (1): 212-224.

Gel'man, V., and T. Lankina. 2008. Authoritarian Versus Democratic Diffusions: Explaining Institutional Choices in Russia's Local Government. Post-Soviet Affairs 24 (1): 40-62.

Gherghina, S. 2013. Going for a Safe Vote: Electoral Bribes in Post-Communist Romania. Debatte: Journal of Contemporary Central and Eastern Europe 21 (2): 143-164.

Gherghina, S., and C. Volintiru. 2017. A New Model of Clientelism: Political Parties, Public Resources, and Private Contributors. European Political Science Review 9 (1): 115-137.

Gibson, E. 2013. Boundary Control: Subnational Authoritarianism in Federal Democracies. New York: Cambridge University Press.

Golosov, G.V. 2013. Machine Politics: The Concept and Its Implications for Post-Soviet Studies. Demokratizatsiya: The Journal of Post-Soviet Democratization 21 (4): 459-480.

Goodnow, R., R.G. Moser and T. Smith. 2014. Ethnicity and Electoral Manipulation in Russia. Electoral Studies 36: 15-27.

Hale, H.E. 2003. Explaining Machine Politics in Russia's Regions: Economy, Ethnicity, and Legacy. Post-Soviet Affairs 19 (3): 228-263.

Hale, H.E. 2007. Correlates of Clientelism: Political Economy, Politicized Ethnicity, and Post-Communist Transition. In Patrons, Clients, and Policies, Patterns of Democratic Accountability and Political Competition, ed. H. Kitschelt and S.I. Wilkinson. Cambridge: Cambridge University Press.

Hale, H.E. 2015. Patronal Politics: Eurasian Regime Dynamics in Comparative Perspective. Cambridge: Cambridge University Press.

Harvey, C.J. 2016. Changes in the Menu of Manipulation: Electoral Fraud, Ballot Stuffing, and Voter Pressure in the Russian 2011 Election. Electoral Studies 41: 105-117.

Hicken, A. 2011. Clientelism. Annual Review of Political Science 14: 289-310.

Kitschelt, H., and S.I. Wilkinson. 2007. Patrons, Clients, and Policies, Patterns of Democratic Accountability and Political Competition. Cambridge: Cambridge University Press.

Kynev, A.V., V.S. Vakhshtain, A.Y. Buzin, and A.E. Lyubarev. 2012. Vybory Prezidenta Rossii 4 marta 2012 goda: Analiticheskiy doklad. Moscow: Golos.

Lankina, T. 2004. Governing the Locals: Local Self-Government and Ethnic Mobilization in Russia. Lanham: Rowman and Littlefield Publishers.

Larreguy, H., J. Marshall, and P. Querubin. 2016. Parties, Brokers, and Voter Mobilization: How Turnout Buying Depends upon the Party's Capacity to Monitor Brokers. American Political Science Review 110 (1): 160-176.

Magaloni, B. 2006. Voting for Autocracy, Hegemonic Party Survival and Its Demise in Mexico. New York: Cambridge University Press.

Mares, I., and L. Young. 2016. Buying, Expropriating, and Stealing Votes. Annual Review of Political Science 19: 267-288.

Mares, I., and B. Zhu. 2015. The Production of Electoral Intimidation, Economic and Political Incentives. Comparative Politics 48 (1): 23-41.

Matzusato, K. 2001a. From Ethno-Bonapartism to Centralized Caciquismo: Characteristics and Origins of the Tatarstan Political Regime, 1900-2000. Journal of Communist Studies and Transition Politics 17 (4): 43-77.

Matzusato, K. 2001b. From Communist Boss Politics to Postcommunist Caciquismo-The Meso-elite and Meso-governments in Post-Communist Countries. Communist and Post-Communist Studies 34: 175-201.

McFaul, M., and N. Petrov. 1998. Politicheskiy al'manakh Rossii 1997. Moscow: Carnegie Moscow Center.

Mebane, W., and K. Kalinin. 2010. Electoral Fraud in Russia: Vote Counts Analysis Using Second-Digit Mean Tests. In MPSA Annual Meeting, Chicago.

Moe, T.M. 1984. The New Economic of Organization. American Journal of Political Science 28 (4): 739-777.

Myagkov, M., P.C. Ordeshook, and D. Shakin. 2005. Fraud or Fairytales: Russia and Ukraine's Electoral Experience. Post-Soviet Affairs 21 (2): 91-131.

Myagkov, M., P.C. Ordeshook, and M. Shakin. 2009. The Forensics of Election Fraud. Cambridge: Cambridge University Press. 
Orttung, R.W., D.N. Lussier, and A. Paretskaya, eds. 2000. The Republics and Regions of the Russian Federation, a Guide to Politics, Policies, and Leaders. Armonk: M. E. Sharpe.

OSCE/ODIHR. 2012. The OCSE/ODIHR Election Observation Mission Report. Presidential Election 4 March 2012. Russian Federation.

Petrov, N.V., and A.S. Titkov. Indeks demokratichnosti. Sotsial'nyi atlas rossiyskikh regionov. http://atlas. socpol.ru/indexes/index_democr.shtml. Accessed 07.11.2007.

Rabe-Hesketh, S., and A. Skrondal. 2005. Multilevel and Longitudinal Modeling Using Stata. College Station: Stata Press.

Reisinger, W.M., and B.J. Moraski. 2017. The Regional Roots of Russia's Political Regime. Ann Arbor: University of Michigan Press.

Reuter, O.J. 2010. The Politics of Dominant Party Formation: United Russia and Russia's Governors. Europe-Asia Studies 62 (2): 293-327.

Reuter, O.J. 2017. The Origins of Dominant Parties: Building Authoritarian Institutions in PostSoviet Russia. New York: Cambridge University Press.

Reuter, O.J., and T.F. Remington. 2009. Dominant Party Regimes and the Commitment Problem: The Case of United Russia. Comparative Political Studies 42 (4): 501-526.

Reuter, O.J., and G. Robertson. 2012. Subnational Appointments in Authoritarian Regimes: Evidence from Russian Gubernatorial Appointments. The Journal of Politics 74 (4): 1023-1037.

Roeder, P. 1993. The Red Sunset: The Failure of Soviet Politics. Princeton: Princeton University Press.

Rundlett, A., and M.W. Svolik. 2016. Deliver the Vote! Micromotives and Macrobehaviour in Electoral Fraud. American Political Science Review 110 (1): 180-197.

Saikkonen, I.A.-L. 2017. Electoral Mobilization and Authoritarian Elections: Evidence from PostSoviet Russia. Government and Opposition 52 (1): 51-74.

Saikkonen, I.A.-L. 2019. Clientelism and Democratic Regression: Evidence from Russia. In Clientelism and Democratic Representation in Comparative Perspective, ed. S. Ruth-Lovell and M. Spirova. London: Rowman and Littlefield Publishers/ECPR Press.

Sharafutdinova, G. 2010. Political Consequences of Crony Capitalism Inside Russia. Indiana: University of Notre Dame Press.

Sharafutdinova, G. 2013. Getting the "Dough" and Saving the Machine: Lessons from Tatarstan. Demokratizatsiya: The Journal of Post-Soviet Democratization 21 (4): 507-529.

Skovoroda, R., and T. Lankina. 2017. Fabricating Votes for Putin: New Tests of Fraud and Electoral Manipulation from Russia. Post-Soviet Affairs 33 (2): 100-123.

Slider, D. 2004. Governors Versus Mayors: The Regional Dimension of Russian Local Government. In The Politics of Local Government in Russia, ed. A.B. Evans and V. Gel'man. Lanham: Rowman and Littlefield Publishers.

Stokes, S.C. 2005. Perverse Accountability: A Formal Model of Machine Politics with Evidence from Argentina. American Political Science Review 99 (3): 315-325.

Stokes, S.C., T. Dunning, M. Nazareno, and V. Brusco. 2013. Brokers, Voters, and Clientelism, the Puzzle of Distributive Politics. New York: Cambridge University Press.

Szwarcberg, M. 2012a. Revisiting Clientelism: A Network Analysis of Problem-Solving Networks in Argentina. Social Networks 34 (2): 230-240.

Szwarcberg, M. 2012b. Uncertainty, Political Clientelism, and Voter Turnout in Latin America: Why Parties Conduct Rallies in Argentina. Comparative Politics 45 (1): 88-106.

Szwarcberg, M. 2013. Building a Following: Local Candidates' Political Careers and Clientelism in Argentine Municipalities. Latin American Politics and Society 55 (3): 1-199.

Treisman, D. 2011. Presidential Popularity in a Hybrid Regime: Russia Under Yeltsin and Putin. American Journal of Political Science 55 (3): 590-609.

White, A. 2016. Electoral Fraud and Electoral Geography: United Russia Strongholds in the 2007 and 2011 Russian Parliamentary Elections. Europe-Asia Studies 56 (7): 1127-1178.

White, A.C., and I.A.-L. Saikkonen. 2017. More Than a Name? Variation in Electoral Mobilization of Titular and Non-titular Ethnic Minorities in Russian National Elections. Ethnopolitics 16 (5): 450-470. https://doi.org/10.1080/17449057.2016.1221186.

Whitehead, L., and J. Behrend, eds. 2016. Illiberal Practices: Territorial Variance Within Large Federal Democracies. Baltimore: Johns Hopkins University Press.

Ziblatt, D. 2009. Shaping Democratic Practice and the Causes of Electoral Fraud: The Case of Nineteenth-Century Germany. American Political Science Review 103 (1): 1-21. 
Publisher's Note Springer Nature remains neutral with regard to jurisdictional claims in published maps and institutional affiliations.

Inga A.-L. Saikkonen is a Academy of Finland Research Fellow at the Social Science Research Institute, Åbo Akademi University. She holds a Doctorate in Politics from the University of Oxford, and has been a Visiting Scholar at Lund University and Columbia University as well as a Postdoctoral Fellow at Yale University. Her work focuses on electoral clientelism, electoral mobilization, democratization and subnational politics. 